This work is licensed under a Creative Commons Attribution 3.0 License.

Research article

urn:1sid:zoobank.org:pub:37D0E672-FD6F-47B5-8768-E34677E02D94

\title{
Redescription of Echinoderes levanderi Karling, 1954 (Kinorhyncha: Cyclorhagida) - a kinorhynch tolerant to very low salinities
}

\author{
Martin V. SØRENSEN \\ Section for GeoGenetics, Natural History Museum of Denmark, Copenhagen, Denmark. \\ Email: mvsorensen@snm.ku.dk
} urn:1sid:zoobank.org:author:4143D650-12FC-4914-93F5-2C39339A7156

\begin{abstract}
The kinorhynch species Echinoderes levanderi Karling, 1954 is redescribed. The species can now be recognized by the presence of spines in middorsal positions on segments $4-8$, and in lateroventral positions on segments 6-9, with lateroventral spines on segment 9 showing sexual dimorphism; tubes in subdorsal and ventrolateral positions on segment 2 , in sublateral positions on segments 4 and 8 , in lateroventral positions on segment 5 , and in laterodorsal positions on segment 10. Furthermore, the enlarged sieve plates on segment 9 make the species highly characteristic. New records of the species extend its distributional range into the Bothnian Bay where the bottom water salinity drops below $5 \mathrm{ppt}$, which is the lowest salinity recorded for a habitat with kinorhynchs.
\end{abstract}

Keywords. Baltic Sea, Echinoderidae, Gulf of Bothnia, meiofauna, meiobenthos, taxonomy.

Sørensen M.V. 2018. Redescription of Echinoderes levanderi Karling, 1954 (Kinorhyncha: Cyclorhagida) - a kinorhynch tolerant to very low salinities. European Journal of Taxonomy 436: 1-17. https://doi.org/10.5852/ejt.2018.436

\section{Introduction}

The Baltic Sea is a northeastern extension of the Atlantic Ocean that passes through the narrow straits between Denmark and Sweden. From Oresund and the straits around the Danish island Funen, the Baltic Sea extends east between Sweden and Germany/Poland, and then bends north between Sweden and the Baltic countries. The northern part, limited by Sweden to the west and Finland to the east, is called the Gulf of Bothnia, which is divided into the Bothnian Sea to the south and the Bothnian Bay to the north (Fig. 1). The Baltic Sea and the Gulf of Bothnia receive enormous quantities of freshwater from the numerous rivers that empty from the surrounding land masses (Voipio 1981). This net inflow of freshwater makes the area brackish, with salinities ranging from 8-20 ppt in the western part of the Baltic Sea, and limnic in the Bothnian Bay, where salinities drop to 3-4 ppt (Axe \& Sahlsten 2001). Altogether, the Baltic Sea and the Gulf of Bothnia represent the world's largest brackish water body (Björck 1995).

Information on kinorhynchs from the Baltic Sea and the Gulf of Bothnia is surprisingly scarce. The first record of kinorhynchs from the Baltic Sea dates back to the monumental monography of Zelinka 
(1928), but since then, there have been extremely few reports. Zelinka (1928) reported no less than three pycnophyid species from the Baltic Sea: Pycnophyes giganteus (Zelinka, 1928), Setaphyes dentatus (Reinhard, 1881), and Setaphyes kielensis (Zelinka, 1928), all from the Kiel Bight. A few years later, Lang (1936) reported Setaphyes flaveolatus (Zelinka, 1928) from Oresund, which connects the Baltic Sea with the more open waters in Kattegat. Higgins (1983) erroneously cited Lang (1936) for also reporting Pycnophyes calmani Southern, 1914 from Oresund, but this record was actually from Gilleleje in Kattegat. Reimer (1963) reported two additional pycnophyid species for the first time from the Baltic Sea, Pycnophyes communis Zelinka, 1928 and Krakenella maxima (Reimer, 1963), both from Kadetrinne

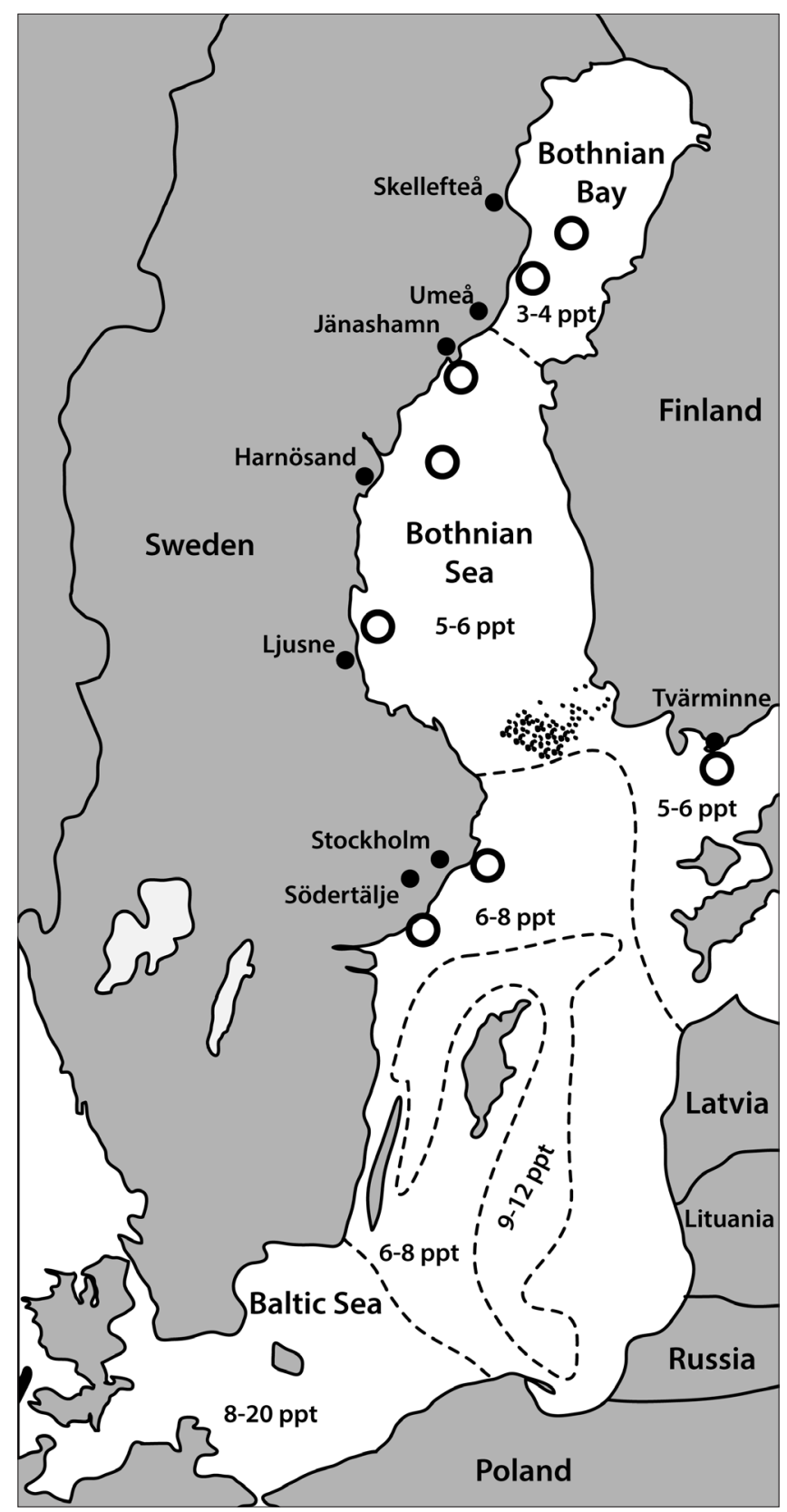

Fig. 1. Map of the Baltic Sea and Gulf of Bothnia, with collecting localities indicated as black rings. Approximate bottom water salinity gradients are indicated with dashed lines (source: Axe \& Sahlsten 2001). 
in the western Baltic Sea, and captured S. kielensis a little further east, on the German coast. This amounts to six pycnophyid species from the Baltic Sea, including $S$. flaveolatus from nearby Oresund.

Yet, the otherwise very abundant genus Echinoderes appears to be poorly represented in the area. Levander (1900) provided the first report of the genus in the region from samples taken around the Alland Islands, at the border between the Baltic Sea and the Bothnian Sea, but the identity of these specimens remains uncertain. The work of Reimer (1963) also includes a single record of Echinoderes subfuscus Zelinka, 1928 from Kadetrinne. The only other known echinoderid from the region is Echinoderes levanderi Karling, 1954, which occurred abundantly in the northern part of the Baltic Sea, from the Stockholm archipelago to the Åland Islands, and in the type locality Tvärminne at the Finnish coast (Karling 1954). This species takes up a special position among kinorhynchs, firstly because it is the only kinorhynch of the Baltic Sea known from the inner parts, but also because it appears to tolerate the lowest salinities. Kinorhynchs are almost exclusively marine organisms and in certain cases brackish, but with salinities around Tvärminne reaching as low as $5 \mathrm{ppt}$, the area can be considered as on the threshold of freshwater.

Karling (1954) provided a description of E. levanderi that was acceptable in his time. However, the number of known species of Echinoderes has since increased tenfold and Karling's diagnosis no longer allows an unambiguous species identification. Thus, to enable identification and to provide more detailed information about the species' morphology, the present contribution presents a redescription of E. levanderi. The redescription includes information from specimens used in Karling's original description, but also newer material that extends the distributional range of $E$. levanderi into the Gulf of Bothnia and into waters with a salinity below 4 ppt.

\section{Material and methods}

\section{Material examined}

Fifteen light microscopical slides with a total of 40 mounted kinorhynch specimens were loaned from the collections of the Swedish Museum of Natural History (catalogue numbers SMNH 128787 and SMNH 157569-157582). Out of these, 31 adult and four juvenile specimens were identified as E. levanderi, whereas one adult and four juveniles were left as undetermined Echinoderes. In addition, Dr O. Holovachov kindly provided four males, three females and two juveniles of E. levanderi that could be mounted for scanning electron microscopy (SEM). Available details on collecting sites and examined specimens are provided in Table 1 and the collecting sites are shown in Fig. 1.

The type material of E. levanderi, including the holotype, has unfortunately been lost and the only available specimen (SMNH 157569) from the type locality at Henriksbergs, Tvärminne, was not mounted very well. However, the material included other specimens collected by Karling at Tvärminne a few years after the description of E. levanderi, as well as specimens from other localities in the Baltic Sea that were sampled by Karling at the time he first described the species. Newer material includes specimens from the Bothnian Sea as far north as the Bothnian Bay (Table 1, Fig. 1).

Not all specimens mounted for light microscopy (LM) were in an optimal condition. Some were dried out, or in a crystallized mounting medium, and many were mounted on the lateral side which hampered observation of some important characters. Still other specimens were well mounted and in good condition, allowing all relevant characters to be observed and documented. Due to the age of many slides, the amount of information related to the collecting localities, sampling, processing and mounting of the species was rather limited. Available information is provided in Table 1. For several slides, the locality was only provided with a name, and not with exact coordinates. For these localities, the approximate positions were found in Google Earth and are listed with degrees and minutes only, between square brackets in the material citations. 
동

总过

की

草

क्ष

.

过.

का

然

बी

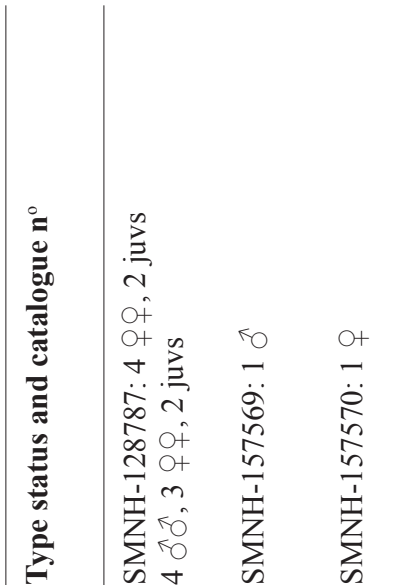

:

¿

苛

递

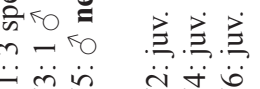

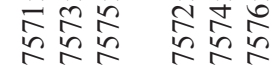

in $\sin ^{2}$ in

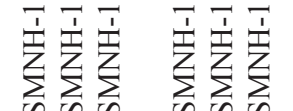

总鸢

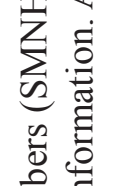

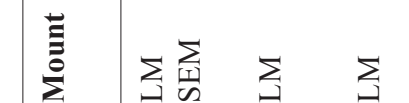

$\sum$

$\Sigma$

$\sum$

of of
O+ Ot
n d

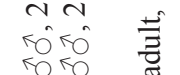

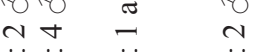

芒芜

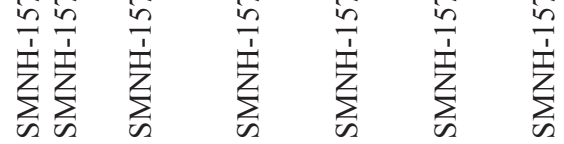

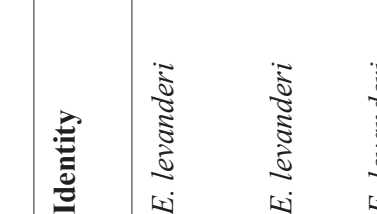

$\frac{2}{3}$

$\frac{\sqrt{2}}{3}$

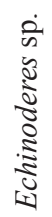

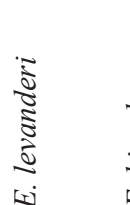

$\sum_{\lrcorner} \sum_{\lrcorner} \sum_{\lrcorner}$

के

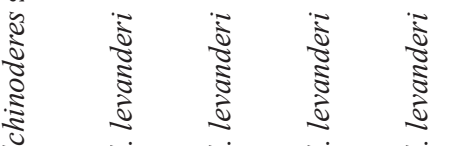

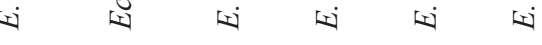

晃

氖

등음

苞 焉

○

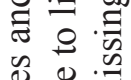

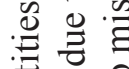

용요

导 莺

s.

के 흘

ڤั

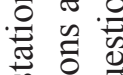

की

욤

䒕

융

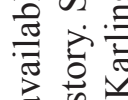

芯谓

空芯

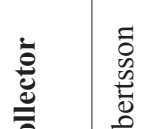

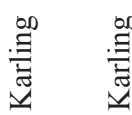

泀

离

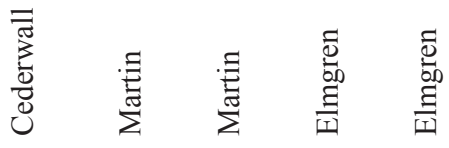

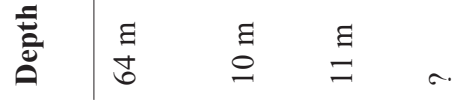

\&

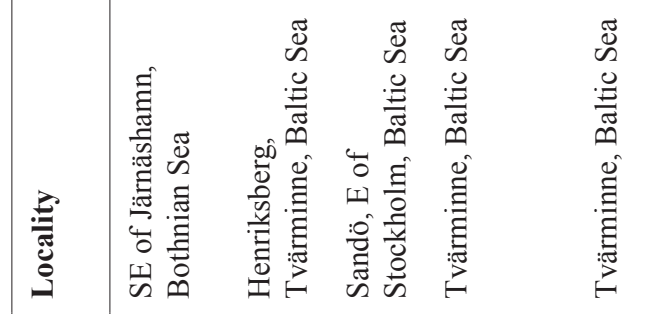

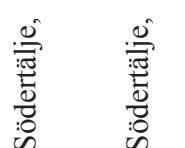

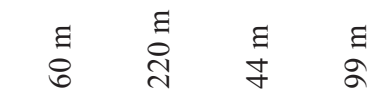

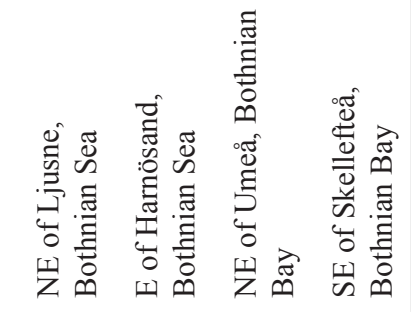

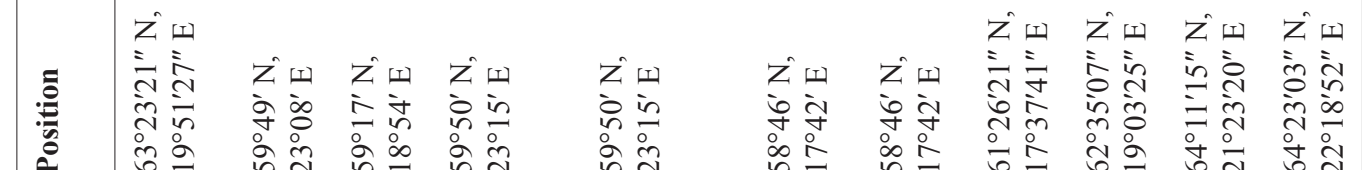

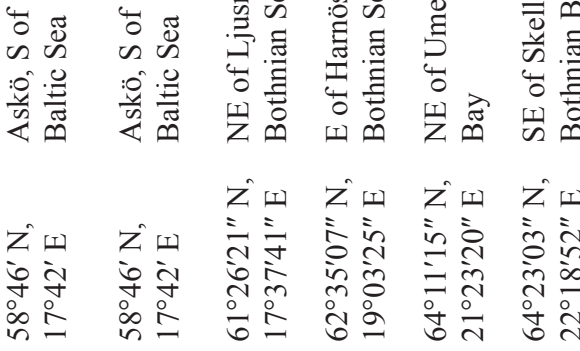

অ)

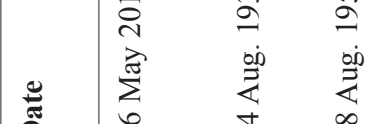

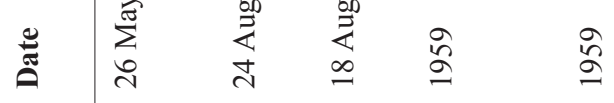

今)

焉蓄

$\stackrel{\text { aे }}{\frac{2}{2}}$

峁

की

竞

号

.. $\quad \stackrel{\text { हू }}{3}$

$\frac{\partial}{2}$ 


\title{
Preparation and microscopy
}

Specimens mounted for LM were examined and photographed with an Olympus BX51 microscope using an Olympus DP27 camera. Line art illustrations were based on LM images, supplemented with information from SEM, and composed in Adobe Illustrator ${ }^{\circledR}$ CS6. Measurements were made with CellSens software. Specimens for SEM were removed from the formalin, rinsed in distilled water, and dehydrated through a graded series of ethanol, and then acetone. The dehydrated specimens were critical point dried, mounted on aluminium stubs using adhesive carbon tabs, and sputter coated with a platinum/palladium mixture. The mounted specimens were examined and photographed with a JEOL JSM-6335F Field Emission SEM.

\section{Results}

\author{
Phylum Kinorhyncha Dujardin, 1851 \\ Class Cyclorhagida (Zelinka, 1896) Sørensen et al., 2015 \\ Order Echinorhagata Sørensen et al., 2015 \\ Family Echinoderidae Zelinka, 1894 \\ Genus Echinoderes Claparède, 1863
}

Echinoderes levanderi Karling, 1954

Figs 2-4, Tables 1-3

\section{Emended diagnosis}

Echinoderes with middorsal spines on segments 4-8, and spines in lateroventral positions on segments 6-9. Lateroventral spines on segment 9 considerably longer in females than in males, projecting beyond segment 11 . Tubes present occasionally in subdorsal and always in ventrolateral positions on segment 2 , in sublateral positions on segments 4 and 8 , in lateroventral positions on segment 5 , and in laterodorsal positions on the posterior margin of segment 10. Glandular cell outlets type 2 not present. Segment 2 with weak indication of midventral fissure. Segment 9 with large oval sieve plates. Tergal extensions of segment 11 are short and pointed, with an additional point on inferior margins. Males with three penile spines; females with lateral terminal accessory spines.

\section{Material examined}

\section{Neotype}

BALTIC SEA: đ’, Tvärminne, [5950’ N, 2315’ E], “Tv1959”, 1959, Karling leg. (SMNH 157575)

\section{Additional material}

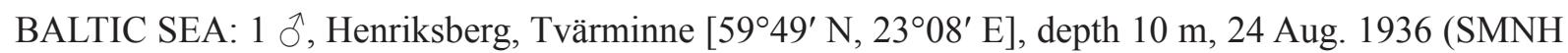

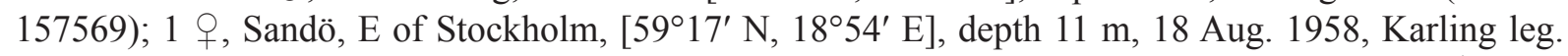
(SMNH 157570); 3 specimens [poor condition], same data as for neotyope (SMNH 157571); $10^{\lambda}$, same

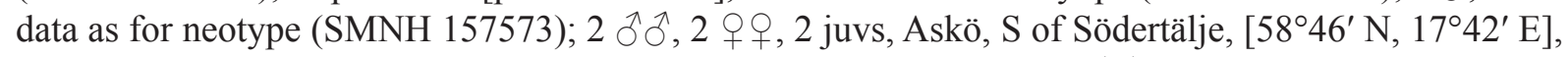

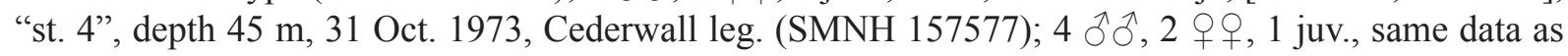
for previous (SMNH 157578).

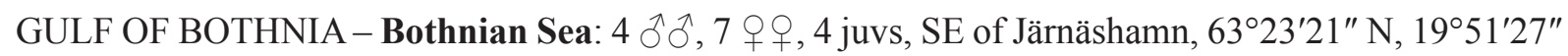

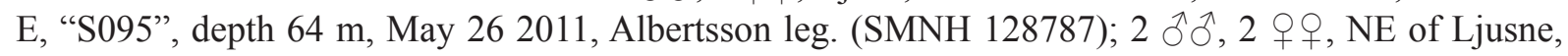
$61^{\circ} 26^{\prime} 21^{\prime \prime} \mathrm{N}, 17^{\circ} 37^{\prime} 41^{\prime \prime} \mathrm{E}$, depth 60 m, 17 Apr. 1974, Martin leg. (SMNH 157579); 1 đ, 2 우, E

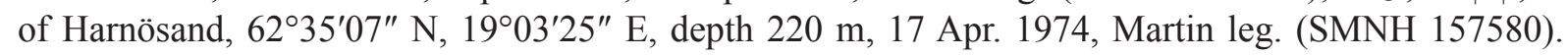

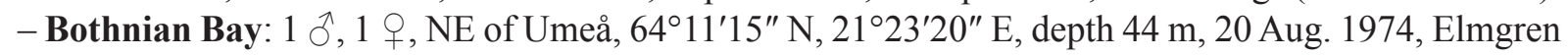




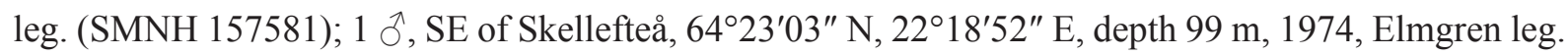
(SMNH 157582).

\section{Redescription}

Adults with head, neck and eleven trunk segments (Figs 2A-B, 3A, 4A). For a complete overview of measures and dimensions, see Table 2. Distribution of cuticular structures, i.e., sensory spots, glandular cell outlets, spines and tubes, is summarized in Table 3.

The head is formed by a retractable mouth cone with nine outer oral styles and an introvert with scalids. The condition of the SEM specimens did not allow a detailed description of the scalid arrangement. The neck has 16 placids, measuring $23 \mu \mathrm{m}$ in length. The midventral placid is broadest, measuring 20 $\mu \mathrm{m}$ in width at its base, whereas all others are narrower, measuring $13 \mu \mathrm{m}$ in width at their bases. The trichoscalid plates are well developed, and located in introvert sectors 2, 4-5, 7-8, and 10. A trichoscalid is attached to each trichoscalid plate.

Segment 1 consists of a complete cuticular ring (Figs 2A-B, 3A-C, 4A-D). Sensory spots are located anteriorly on the segment in subdorsal and laterodorsal positions (Figs 2A, 4B, D), and more posteriorly in ventromedial positions (Figs 2B, 4C). On this and the following two segments, the sensory spots are medium sized and rounded or slightly oval, and made up by numerous micropapillae around a central pore. Glandular cell outlets type 1 are present in middorsal and ventrolateral positions. Cuticular hairs emerge through rounded perforation sites, covering the dorsal and lateral sides densely, whereas the ventral side has a large W-shaped area without hairs (Fig. 4C). The posterior segment margin terminates into a pectinate fringe with long and slender fringe tips.

Segment 2 consists of a complete cuticular ring, but with weak indications on a midventral fissure, visible both inside the cuticle (Fig. 3C) and on the surface (Fig. 4E). Pachycyclus of the anterior segment margin is of regular thickness and not interrupted. All specimens with tubes present in ventrolateral positions (Figs 2B, 3C, 4E); in addition, some (Figs 2A, 3B, 4D), but not all (Fig. 4B) with tubes in subdorsal positions; subdorsal tubes present in at least nine specimens, and certainly lacking in eight specimens, whereas eventual presence or absence could not be confirmed with certainty for the remaining specimens. Presence or absence of subdorsal tubes does not appear to be correlated with the specimens' gender. Sensory spots are located in middorsal (Fig. 4B), midlateral (Fig. 4D) and ventromedial (Fig. 4E) positions. Glandular cell outlets type 1 are present in middorsal positions. Secondary pectinate fringe present as single fringe with rather short fringe tips on anterior part of segment. On this and all following segments, the cuticular hairs are bracteate. Hairs are densely distributed around the segment, except on the ventral-most halves of the sternal plates, that only have a few, short filiform hair-like extensions. Pectinate fringe of posterior margin as on preceding segment, but with slightly longer fringe tips.

Segment 3, and remaining segments, consisting of one tergal and two sternal plates (Figs 2A-B, 3A, C, E, 4E). Sensory spots are located in subdorsal, sublateral and ventromedial positions (Figs 2A-B, 4D-E). Glandular cell outlets type 1 present in middorsal and ventromedial positions (Figs 2A-B, 3E). Secondary pectinate fringe and cuticular hairs as on preceding segment. Pectinate fringe of posterior margin as on preceding segment, but with slightly longer fringe tips.

Segment 4 with acicular spine in middorsal position and tubes in sublateral positions (Figs 2B, 3E, 4F). Sensory spots present in laterodorsal and ventromedial positions (Figs 2A-B, 4D-E); from this segment and onwards, sensory spots are more elongate and droplet- to wedge-shaped. Glandular cell outlets type 1 located in paradorsal and ventromedial positions (Figs 2A-B, 3E). Pachycycli, secondary fringe; pectinate fringe of posterior margin and cuticular hairs as on preceding segment. 

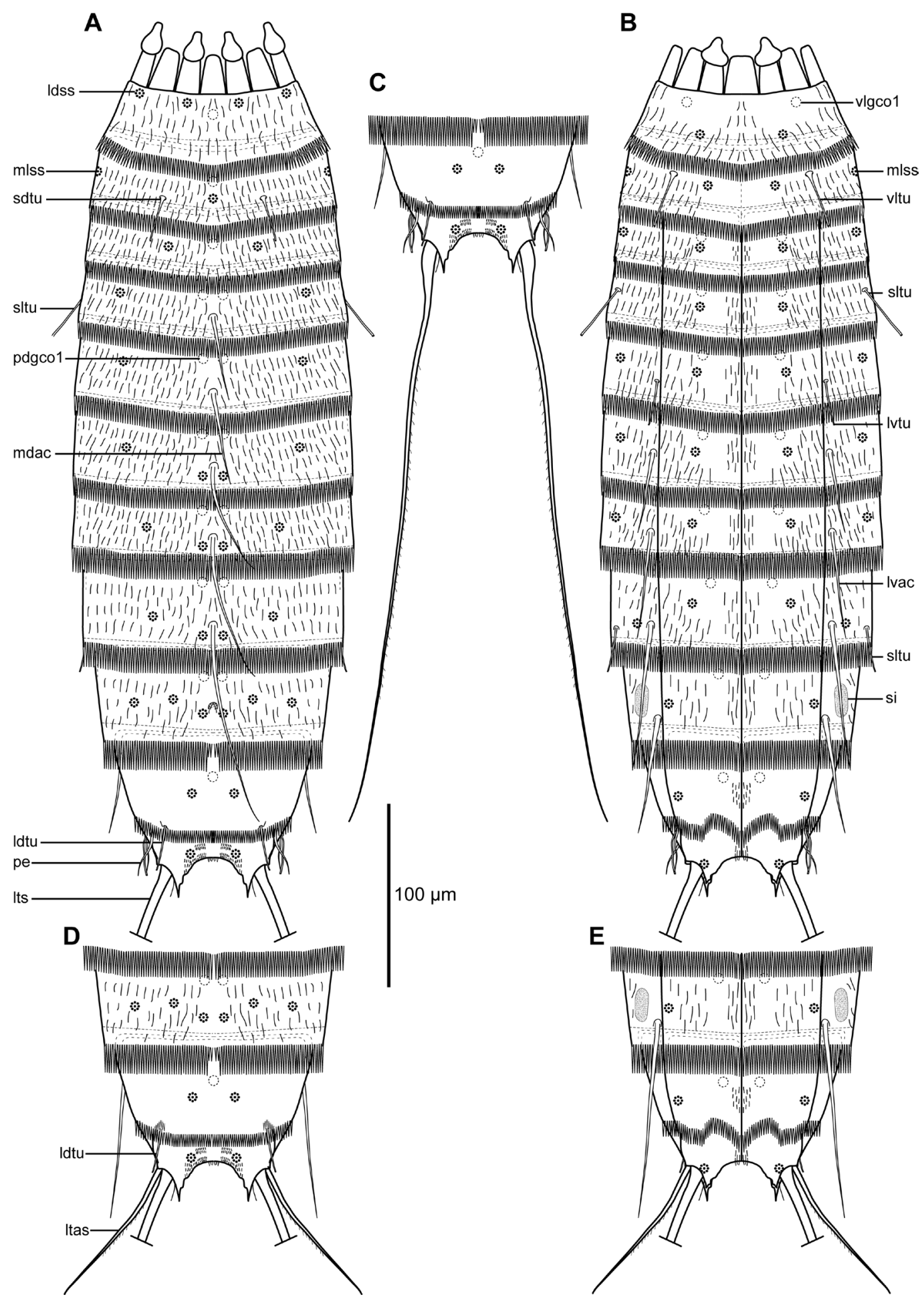

Fig. 2. Line art illustration of Echinoderes levanderi Karling, 1954. A. $\hat{\jmath}$, dorsal overview. B. $\widehat{\partial}$, ventral overview. C. Oे, segments 10-11 with lateral terminal spines drawn to full length, dorsal view. D. + , segments 9-11, dorsal view. E. o, segments 9-11, ventral view. Abbreviations: ldss, laterodorsal sensory spot; ldtu, laterodorsal tube; ltas, lateral terminal accessory spine; lts, lateral terminal spine; lvac, lateroventral acicular spine; lvtu, lateroventral tube; mdac, middorsal acicular spine; mlss, midlateral sensory spot; pdgco1, paradorsal glandular cell outlet type 1; pe, penile spines; sdtu, subdorsal tube; sltu, sublateral tube; si, sieve plate; vlgco1, ventrolateral glandular cell outlet type 1; vltu, ventrolateral tube 

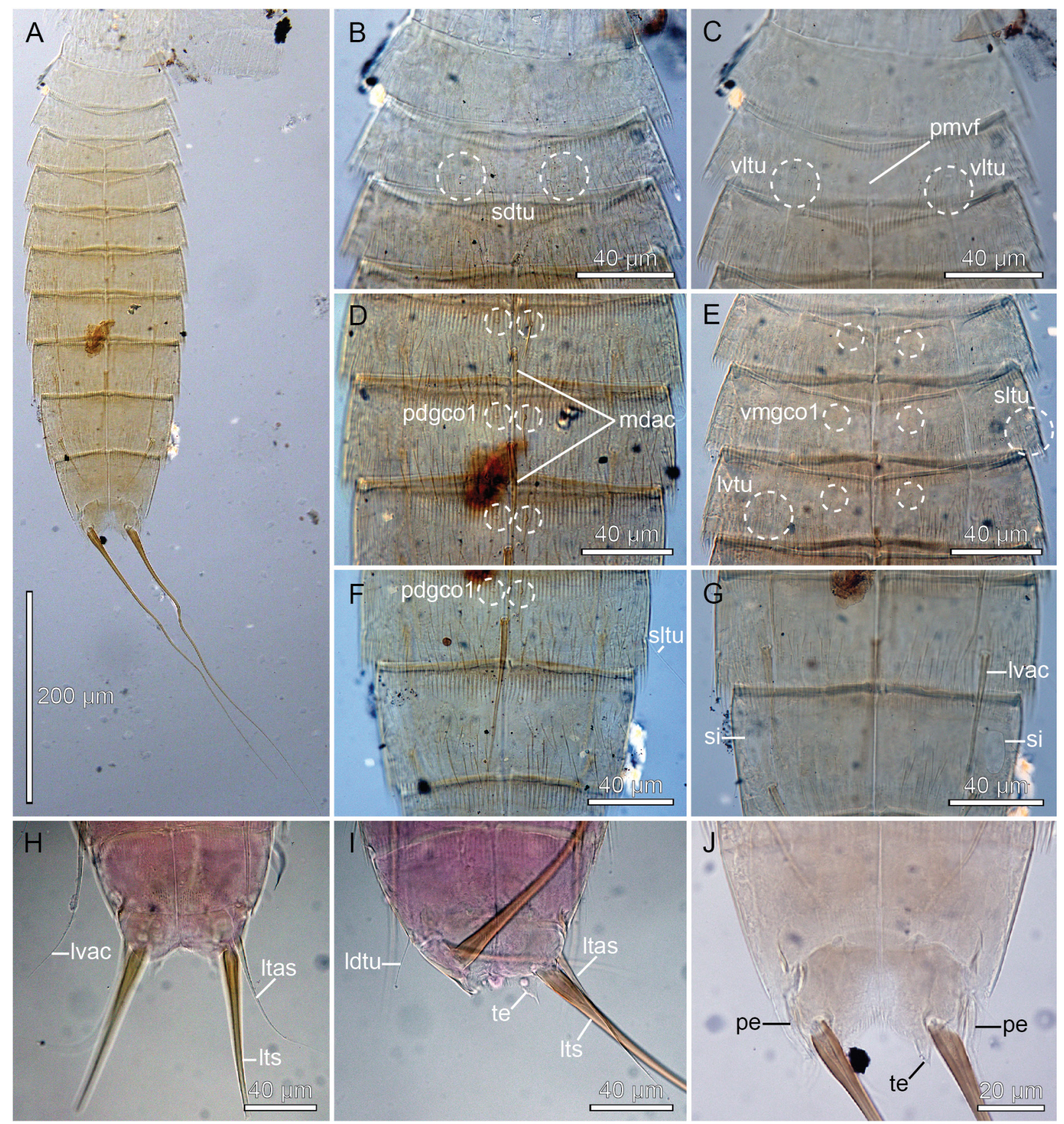

Fig. 3. Light electron micrographs of Echinoderes levanderi Karling, 1954. A-G, J. Neotype, o (SMNH 157575). H. क (SMNH 157577d). I. q (SMNH 157577a). A. Ventral overview. B. Segments 1-3, dorsal view. C. Segments 1-3, ventral view. D. Segments 6-8, dorsal view. E. Segments 3-5, ventral view. F. Segments 8-9, dorsal view. G. Segments 8-9, ventral view. H-I. Segments 10-11, ventral view. J. Segment 10-11, ventral view. Abbreviations: ldtu, laterodorsal tube; ltas, lateral terminal accessory spine; lts, lateral terminal spine; lvac, lateroventral acicular spine; lvtu, lateroventral tube; mdac, middorsal acicular spine; pdgco1, paradorsal glandular cell outlet type 1; pe, penile spines; pmvf, partial midventral fissure; sdtu, subdorsal tube; sltu, sublateral tube; si, sieve plate; te, tergal extension; vltu, ventrolateral tube; vmgco1, ventromedial glandular cell outlet type 1. 

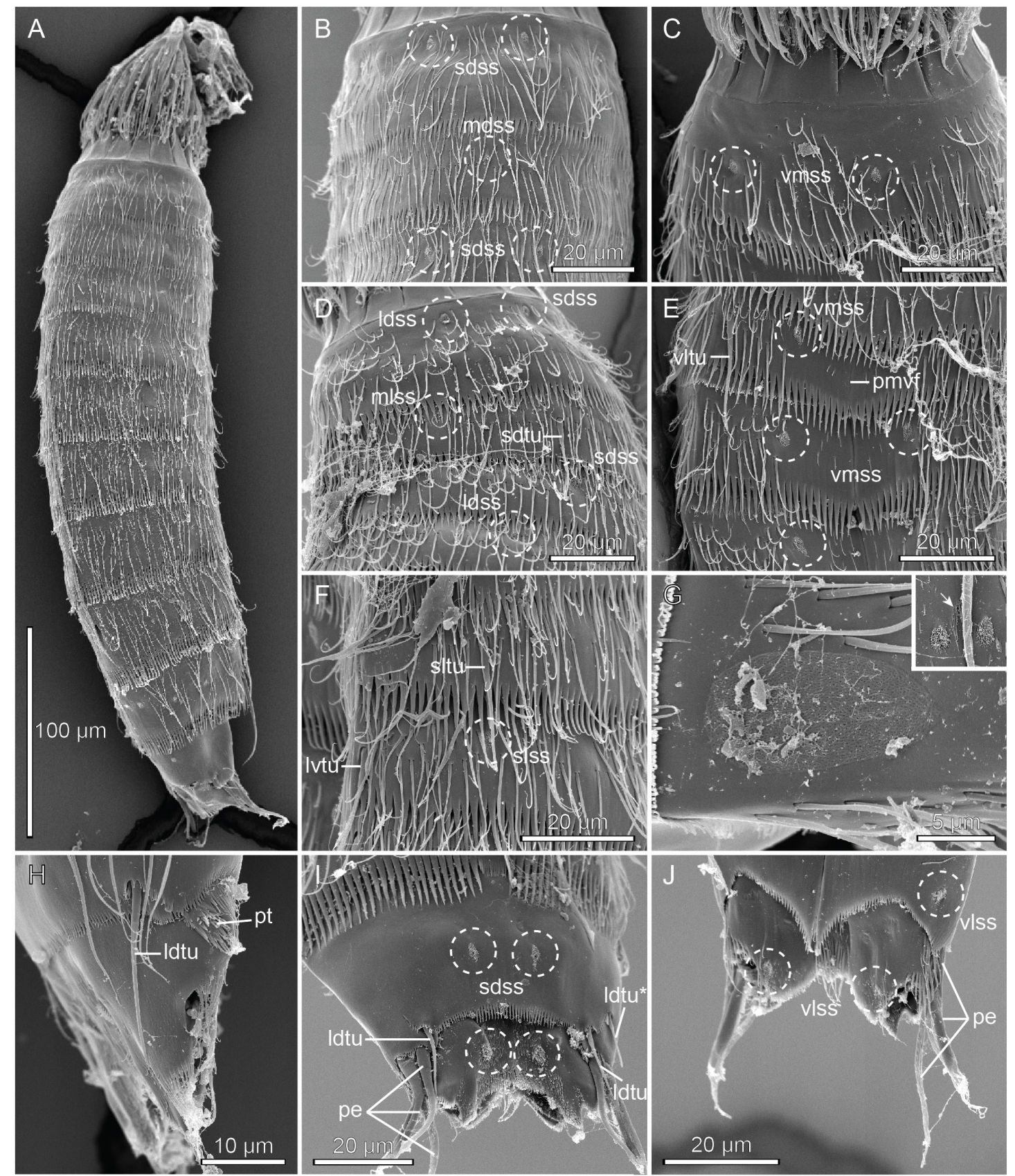

Fig. 4. Scanning electron micrographs of Echinoderes levanderi Karling, 1954. A. $\$$, laterodorsal overview. B. O, segments 1-3, dorsal view, note the absence of subdorsal tubes. C. 0 , segment 1 ,

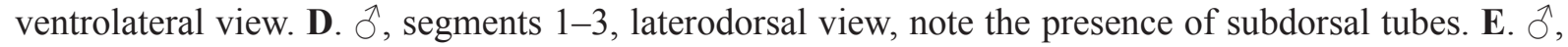
segments 2-3, ventral view. F. $\hat{\jmath}$, segments 4-5, sublateral view. G. $\widehat{\jmath}$, details of segments 9, showing sublateral sieve plates and middorsal cuticular scar (arrow, inset). H. + , segment 11, lateral view. I. $\delta^{\lambda}$, segments 10-11, subdorsal view. (* marks additional ldtu found in this specimen only). J. ${ }^{\lambda}$, segment 11, ventrolateral view. Note that lateral terminal spines are broken off in all specimens. Abbreviations: 1dss, laterodorsal sensory spot; ldtu, laterodorsal tube (* marks additional, ldtu found in this specimen only); lvtu, lateroventral tube; mdss, middorsal sensory spot; mlss, midlateral sensory spot; pe, penile spines; pmvf, partial midventral fissure; pt, papillar tuft; sdss, subdorsal sensory spot; sdtu, subdorsal tube; slss, sublateral sensory spot; sltu, sublateral tube; vlss, ventrolateral sensory spot; vltu, ventrolateral tube; vmss, ventromedial sensory spot 
Table 2. Measurements from light microscopy of Echinoderes levanderi Karling, 1954 (in $\mu \mathrm{m}$ ), including number of measured specimens (n) and standard deviation (SD). $q=$ female condition of sexually dimorphic character; $\hat{\jmath}=$ male condition of sexually dimorphic character. Abbreviations: $(\mathrm{ac})$ : acicular spine; LTAS: lateral terminal accessory spine; LTS: lateral terminal spine; LV: lateroventral; MD, middorsal; ML: midlateral; MSW-5: maximum sternal width, measured on segment 5 in this species; S: segment lengths; S10-11: combined length of segments 10 and 11; SL: sublateral; SW-10, standard width, always measured on segment 10; TL: trunk length; (tu): tube; +, female condition of sexually dimorphic character; $\hat{\partial}$, male condition of sexually dimorphic character.

\begin{tabular}{lcccc}
\hline Character & $\mathbf{n}$ & Range & Mean & SD \\
\hline TL & 9 & $335-463$ & 410 & 44.83 \\
MSW-5 & 7 & $81-94$ & 88 & 5.10 \\
MSW-5/TL & 7 & $19.5-26.0 \%$ & $21.2 \%$ & $2.32 \%$ \\
SW-10 & 9 & $72-87$ & 80 & 5.65 \\
SW-10/TL & 7 & $16.4-24.8$ & $19.9 \%$ & $3.38 \%$ \\
S1 & 10 & $33-44$ & 39 & 3.07 \\
S2 & 10 & $37-45$ & 41 & 2.51 \\
S3 & 10 & $42-49$ & 44 & 2.16 \\
S4 & 10 & $44-54$ & 50 & 3.40 \\
S5 & 10 & $50-61$ & 54 & 3.05 \\
S6 & 10 & $52-64$ & 57 & 3.96 \\
S7 & 11 & $55-70$ & 60 & 4.48 \\
S8 & 11 & $58-72$ & 65 & 4.64 \\
S9 & 11 & $65-78$ & 71 & 3.88 \\
S10 & 11 & $47-64$ & 56 & 5.16 \\
S11 & 11 & $39-48$ & 43 & 2.71 \\
MD4 (ac) & 6 & $36-46$ & 42 & 3.49 \\
MD5 (ac) & 6 & $47-59$ & 52 & 4.97 \\
MD6 (ac) & 6 & $46-66$ & 59 & 7.39 \\
MD7 (ac) & 8 & $61-89$ & 74 & 9.78 \\
MD8 (ac) & 9 & $84-110$ & 95 & 9.26 \\
ML4 (tu) & 2 & $32-40$ & 36 & 5.66 \\
SL8 (tu) & 2 & $30-36$ & 33 & 4.24 \\
LV6 (ac) & 8 & $41-54$ & 48 & 4.02 \\
LV7 (ac) & 11 & $46-74$ & 58 & 8.86 \\
LV8 (ac) & 11 & $49-75$ & 68 & 4.84 \\
LV9 (ac) & 12 & $51-66$ & 58 & 4.41 \\
LV9 (ac) 9 & 13 & $96-121$ & 106 & 7.09 \\
LV9 (ac)/S10-11 & 12 & $59.3-92.1 \%$ & 69.8 & $9.20 \%$ \\
LV9 (ac)/S10-11 +9 & 11 & $108.9-133.0 \%$ & $116.9 \%$ & $7.30 \%$ \\
lts & 8 & $332-380$ & 359 & 16.24 \\
lts/TL & 7 & $81.6-105.6 \%$ & $90.5 \%$ & $9.30 \%$ \\
ltas + & 3 & $91-98$ & 95 & 3.79 \\
\hline
\end{tabular}


Table 3. Summary of nature and location of sensory spots, glandular cell outlets, tubes and spines arranged by series in Echinoderes levanderi Karling, 1954. $q=$ female condition of sexually dimorphic character; $\hat{\partial}=$ male condition of sexually dimorphic characters. Abbreviations: LA: lateral accessory; LD: Laterodorsal; LV: lateroventral; MD: middorsal; ML: midlateral; PD: paradorsal; SD: subdorsal; SL: sublateral; VL: ventrolateral; VM: ventromedial; ac, acicular spine; gco1, glandular cell outlet type 1; Itas, lateral terminal accessory spine; lts, lateral terminal spine; pe, penile spines; si, sieve plate; ss, sensory spot; tu, tube; + , female condition of sexually dimorphic character; $\hat{O}$, male condition of sexually dimorphic characters; * marks structures that do not appear consistently in all specimens; \# marks asymmetrical structures present only in one side of the specimen.

\begin{tabular}{|c|c|c|c|c|c|c|c|c|c|c|}
\hline Segment & MD & PD & SD & LD & ML & SL & LA & LV & VL & VM \\
\hline 1 & gco1 & - & ss & ss & - & - & - & - & gcol & ss \\
\hline 2 & gcol, ss & - & $\mathrm{tu}^{*}$ & - & ss & - & - & - & tu & ss \\
\hline 3 & gco1 & - & ss & - & - & Ss & - & - & - & $\mathrm{ss}, \mathrm{gco}$ \\
\hline 4 & $\mathrm{ac}$ & gco1 & - & Ss & - & tu & - & - & - & ss, gco \\
\hline 5 & $\mathrm{ac}$ & gcol & - & SS & - & SS & - & tu & - & $\mathrm{ss}, \mathrm{gco}$ \\
\hline 6 & $\mathrm{ac}$ & gcol, ss & - & SS & - & Ss & - & $\mathrm{ac}$ & - & $\mathrm{ss}, \mathrm{gco}$ \\
\hline 7 & $\mathrm{ac}$ & gcol, ss & SS & - & - & SS & - & ac & - & ss, gco \\
\hline 8 & $\mathrm{ac}$ & gcol, ss & ss & - & - & tu & ss & $\mathrm{ac}$ & - & $\mathrm{ss}, \mathrm{gco}$ \\
\hline 9 & - & gcol, ss & Ss & ss & - & si & - & $\mathrm{ac}$ & SS & gco1 \\
\hline 10 & gco1 & - & Ss & $\mathrm{tu}, \mathrm{tu} * \#$ & - & - & - & - & ss & gco1 \\
\hline 11 & - & - & Ss & - & pe $\left(0^{\pi}\right)$ & - & ltas $($ (†) & lts & SS & - \\
\hline
\end{tabular}

Segment 5 with acicular spine in middorsal position and tubes in lateroventral positions (Figs 2A-B, 3E, 4F). Sensory spots present in laterodorsal, sublateral and ventromedial positions (Figs 2A-B, 4F). Glandular cell outlets type 1, pachycycli, secondary fringe, pectinate fringe of posterior margin and cuticular hairs as on preceding segment.

Segments 6 and 7 are almost identical, with acicular spines in middorsal and lateroventral positions (Figs 2A-B), and sensory spots in paradorsal, laterodorsal (segment 6 only), subdorsal (segment 7 only), sublateral and ventromedial positions. Glandular cell outlets type 1 (Fig. 3D), pachycycli, secondary fringe, pectinate fringe of posterior margin and cuticular hairs as on preceding segment.

Segment 8 with acicular spines in middorsal and lateroventral positions. Tubes present in sublateral positions (Figs 2B, 3F). Sensory spots present in paradorsal, subdorsal, lateral accessory and ventromedial positions. Glandular cell outlets type 1 (Fig. 3F), pachycycli, secondary fringe, pectinate fringe of posterior margin and cuticular hairs as on preceding segment.

Segment 9 without middorsal spine, but with acicular spines in lateroventral positions. Length of lateroventral spines show sexual dimorphism, with the female spines being about twice as long as the male spines and hence extending beyond the posterior margin of segment 11 (see Figs $2 \mathrm{~A}-\mathrm{E}, 3 \mathrm{H}, 3 \mathrm{~J}$ and Table 2). Sensory spots present in paradorsal, subdorsal, laterodorsal and ventrolateral positions. A cuticular depression or scar, lined with short hair, is present in middorsal position, in between the paradorsal sensory spots (Figs 2A, 4G inset). Large oval sieve plates, with uniformly distributed pores present in sublateral positions (Figs 2B, 3G, 4G). Pectinate fringe of posterior segment margin as on preceding segment, except in the middorsal position, where the fringe tips are considerably shorter 
(Figs 2A, 4I). Glandular cell outlets type 1, pachycycli, secondary fringe and cuticular hairs as on preceding segment.

Segment 10 with laterodorsal tubes at the posterior segment margin: tubes are well-developed in both sexes (Figs 2, 3I, 4H-I); a single specimen had one additional tube, but only in the right side (Fig. 4I). Sensory spots present in subdorsal (Figs 2A, 4I) and ventrolateral (Figs 2B, 4J) positions. Glandular cell outlets type 1 located in middorsal and ventromedial positions. The segment is completely devoid of cuticular hairs (Figs 4H-J). Pectinate fringe of posterior segment margin present, but with considerably shorter fringe tips compared to preceding segments. Pachycycli and secondary fringe as on preceding segment.

Segment 11 with long lateral terminal spines (Figs 2C, 3A) that almost equal the trunk length (see lts/TL ratio in Table 2). Females with thin but otherwise well-developed lateral terminal accessory spines (Figs 2D-E, 3H-I). Lateral terminal accessory spines lined with numerous, marginal hairs. Females with additional midlateral tufts of papillae, emerging from the transition between segment 10 and 11 (Fig. $4 \mathrm{H}$ ). Males with three pairs of thin and tubular penile spines (Figs 2A-C, 3J, 4J). Sensory spots present in subdorsal (Fig. 4I) and ventrolateral (Fig. 4J) positions. Glandular cell outlets type 1 not present. The segment is completely devoid of cuticular hairs in both sexes, but is densely covered with short hair-like cuticular extensions in subdorsal positions and along the margin between the tergal extensions (Fig. 4I); ventral side with longer hair-like extensions in paraventral positions (Fig. 4J). Tergal extensions are short and pointed, with an additional point on each inferior margin (Figs 2A-E, 3I-J). Sternal extensions are triangular, and slightly shorter than tergal ones (Fig. 4J).

\section{Discussion}

\section{Comparison with original description of $E$. levanderi}

Unfortunately, the original description by Karling (1954) is rather simplistic and several important characters, such as the tubes, are not reported. Hence, it does not leave many clues that allow for the identity of the specimens used in the redescription to be confirmed. Basically, Karling describes an Echinoderes with middorsal spines on segments 4-8, and lateroventral spines on segments 6-9, which is the most typical spine pattern among all species of Echinoderes. However, some information in the description is still useful.

Karling illustrates the holotypic female (Karling 1954: fig. 1), and shows how the lateroventral spines of segment 9 extend well beyond the terminal trunk segment. This fits with the morphology in the specimens used for the redescription, and even though the trait is not unique among species of Echinoderes, it is at least relatively uncommon. Karling also showed posterior segment margins with relatively long and slender fringe tips (Karling 1954: fig. 4) and pointed tergal extensions of segment 11 with a small tooth on the inferior margins (Karling 1954: figs 3, 6), both of these traits fit well with the redescription. Lateral terminal spines of roughly equal length to the trunk were also observed on the specimens examined. Besides this, most other measurements reported by Karling are a bit higher than those observed in the present study. In conclusion, based on the similarities mentioned above and the concording sampling localities, it is probable that the species examined herein is identical to the one described by Karling (1954).

\section{Remarks on diagnostic characters}

The easiest and safest way to distinguish E. levanderi from its congeners is by the combined presence of large oval sieve plates on segment 9 (Figs 3G, 4G) and middorsal spines on segments 4-8. No other kinorhynch species show this combination of characters. The enlarged sieve plates are a character trait that was previously considered as restricted to species of the Echinoderes coulli-group only (e.g., 
Sørensen 2014; Herranz \& Leander 2016; Yamasaki 2016), but species of this group have either no middorsal spines or only a short middorsal spine on segment 4 . The enlarged sieve plates and the Echinoderes coulli-group will be addressed in a dedicated section below.

Besides the combination of enlarged sieve plates and middorsal spines, E. levanderi shows other unique or rare character traits. The presence of sublateral tubes on segment 4 is unique among congeners and the only other species with tubes on segment 4, but in the midlateral positions, is E. augustae Sørensen \& Landers, 2015 (Sørensen \& Landers 2014). However, E. augustae is easily distinguished from E. levanderi by its short, stout lateral terminal spines. The presence of tubes on segment 8 in sublateral positions is also shared with E. augustae, as well as four additional species: E. astridae Sørensen, 2014, E. regina Yamasaki, 2016, E. reicherti Neves et al., 2016 and E. serratulus Yamasaki, 2016 (see Sørensen 2014; Neves et al. 2016; Yamasaki 2016). These species are, however, easily distinguished from $E$. levanderi by their lower numbers of middorsal spines: $E$. astridae has only two middorsal spines, on segments 4 and 6; E. regina, E. reicherti and E. serratulus have only one, on segment 4.

The sexual dimorphism expressed in spine lengths is also a rather unusual trait. In the examined specimens of E. levanderi, the difference was very conspicuous when observing the lateroventral spines of segment 9 in males, which were always considerably shorter than those in females. The size ranges between the genders never overlapped (see Table 2), and the shortest measured female spine was $30 \mu \mathrm{m}$ longer than the longest male spine. Consequently, the lateroventral spines of segment 9 in females were always longer than the combined length of segments 10 and 11, making them project beyond the terminal segment of the trunk. In contrast, the corresponding male spines were shorter than segments 10 and 11 combined, and hence never projecting, which made it very easy to compare the relative lengths of the spines in the two sexes, even without measuring. Sexual dimorphism expressed in spine lengths is not common among species of Echinoderes.

Among the examined specimens of E. levanderi, the presence of subdorsal tubes on segment 2 appeared to show intraspecific variation. Independent of gender and locality, some specimens had subdorsal tubes, whereas others did not. The presence of tubes has commonly been considered a consistent and valid character with high significance for identifying species of Echinoderes. However, Grzelak \& Sørensen (2017) recently showed a similar polymorphism in presence or absence of tubes on segment 9 in E. eximus Higgins \& Kristensen, 1988. Other recent and yet unpublished studies of Grzelak \& Sørensen show the same variation of tubes on segment 8 in E. arlis Higgins, 1966. Finding a similar intraspecific variation in tubes among specimens of $E$. levanderi stresses the importance of collecting data from as many specimens as possible, in order to reveal this kind of variation. It furthermore shows that presence or absence of tubes should be used with some caution when distinguishing species.

\section{Remarks on the composition of segment 2}

Species of Echinoderes have traditionally been distinguished from other genera of Echinoderidae by the composition of segment 2 being formed by a completely closed cuticular ring (e.g., Higgins 1983; Neuhaus 2013; Sørensen et al. 2015). However, it has since been established that some species, e.g., E. aureus Adrianov, Murakami \& Shirayama, 2002, actually show a partially developed midventral intracuticular fissure in segment 2 (Adrianov et al. 2002). Herranz et al. (2018) recently addressed this inconsistency between the genus diagnosis and the actual variability of segment 2 morphology among species of Echinoderes. They demonstrated that several species of the genus actually show signs of partially developed midventral fissures and accordingly emended the genus diagnosis. Novel observations from the present contribution add E. levanderi to the list of Echinoderes with a partial midventral fissure on segment 2 . The phylogenetic significance of this character trait remains unclear, but the observed polymorphy within Echinoderes should lead us to consider the validity of other echinoderid genera, such as Meristoderes (Herranz, Thormar, Benito, Sánchez \& Pardos, 2012) and 
Cephalorhyncha (Adrianov, 1999), for which the presence of partially developed fissures on segment 2 play a pivotal role in the genus definitions.

\section{Remarks on ecology and occurrence at extremely low salinities}

Kinorhynchs are usually considered to be a group of exclusively marine animals (Neuhaus 2013), including a minority of species that also tolerate stable brackish habitats (see, for instance, species mentioned in the Introduction), as well as species of the Echinoderes coulli-group that are adapted to tolerate high daily and seasonal fluctuations in salinity (Sørensen 2014; Yamasaki 2016). No kinorhynchs have previously been reported from water with a salinity below 5 ppt. However, with the expanded distribution of E. levanderi, the species is now reported from localities so far north in the Bothnian Bay (Fig. 1) that the bottom salinity drops to 3.5-4 ppt (Axe \& Sahlsten 2001), which is on the threshold between brackish and freshwater. This obviously does not make kinorhynchs a significant component of the limnic fauna, but it demonstrates that 'nearly freshwater' estuarine habitats might be suitable for kinorhynchs.

Other Echinoderes that tolerate low salinity are species of the Echinoderes coulli-group. One of the key characters that unites the species of this group is their enlarged sieve plates. For E. coulli Higgins, 1977, it has been suggested that this trait could be an adaptation to the osmoregulatory challenges the species faces in its intertidal and highly dynamic habitat (Kristensen \& Higgins 1991). If enlarged sieve plates facilitate a more efficient osmoregulation, this could be the adaptation that enables $E$. levanderi to tolerate the extremely low salinity in the Gulf of Bothnia.

\section{Comparison with species of the Echinoderes coulli-group}

The Echinoderes coulli-group is a putatively monophyletic clade of species within Echinoderes (see, e.g., Sørensen 2014; Sørensen et al. 2016; Herranz \& Leander 2016; Pardos et al. 2016; Yamasaki 2016). The species group currently accommodates 14 species, which share the common characters of an enlarged sieve plate and a reduced number of spines which, when present, are very short. Furthermore, all species (except E. rex Lundbye, Rho \& Sørensen, 2011) are intertidal or estuarine, and eight of the 14 species lack lateral terminal accessory spines in females, which is otherwise a common female character among species of Echinoderes.

The enlarged sieve plates in E. levanderi are reminiscent of the Echinoderes coulli-group and suggest that $E$. levanderi could be considered part of this group. However, besides the size of the sieve plates, no other morphological traits point the species in this direction. All spines, including lateral terminal accessory spines in females, are well developed, and E. levanderi appears to be a mostly subtidal species. Furthermore, even though E. levanderi possesses large sieve plates, it differs morphologically from those found among species of the E. coulli-group. In all species within this group for which detailed morphological information is available (i.e., all except E. bengalensis Timm, 1958 and E. caribiensis Kirsteuer, 1964), the sieve plates consist of a large elongate or triangular pore field anterior to a diskshaped depressed area with a central pore (Lundbye et al. 2011; Ostmann et al. 2012; Yamasaki \& Kajihara 2012; Sørensen 2014, unpubl. obs.; Yamasaki \& Fujimoto 2014; Sørensen et al. 2016; Yamasaki 2016). However, the sieve plates of E. levanderi consist exclusively of the porous areas, whereas the depressed areas with the central pore are missing. This suggests that the enlarged sieve plates in this species are not homologous with the enlargement found among species of the E. coulli-group. Hence, rather than including $E$. levanderi in the $E$. coulli-group, it appears more likely that the enlarged sieve plates in E. levanderi have convergently evolved as an adaptation to cope with the low salinity. 


\section{Conclusions}

Echinoderes levanderi is the kinorhynch known to tolerate the lowest salinities, as low as $3.5 \mathrm{ppt}$. It is found abundantly throughout the Gulf of Bothnia and in the inner parts of the Baltic Sea, and this distribution suggests that the species has adapted to live in habitats with very low salinity. The species is easily recognized by the presence of sublateral tubes on segment 4 and the combined occurrence of five middorsal spines and an enlarged sieve plate on segment 9. The latter character suggests that the species could be closely related to the E. coulli-group. However, since no other characters link E. levanderi to this group and the sieve plates differ in morphology, it is more likely that its large sieve plates represent a convergently evolved adaptation to tolerate the low Baltic and Bothnian water salinity.

\section{Acknowledgments}

I would like to thank the staff of the Swedish Natural History Museum for providing specimens for the present study, in particular curator Ulf Jondelius for handling the loan, Oleksandr Holovachov for providing specimens for SEM examinations, and Sven Boström for proving information about the specimens, and helping to locate the unfortunately lost type specimens.

\section{References}

Adrianov A.V., Murakami C. \& Shirayama Y. 2002. Echinoderes aureus n. sp. (Kinorhyncha: Cyclorhagida) from Tanabe Bay (Honshu) - first representative of the genus in the Pacific Ocean. Proceedings of the Biological Society of Washington 115: 205-216.

Axe P. \& Sahlsten E. 2001. Hydrografi/hydrokemi. Bottniska Viken 2001.

Available from http://www.havet.nu/dokument/Bv2001hydro.pdf [accessed 5 Oct. 2017].

Björck S. 1995. A review of the history of the Baltic Sea, 13.0-8.0 ka BP. Quaternary International 27: $19-40$.

Grzelak K. \& Sørensen M.V. 2018. New species of Echinoderes (Kinorhyncha: Cyclorhagida) from Spitsbergen, with additional information about Arctic species. Marine Biology Research 14 (2):113-147. https://doi.org/10.1080/17451000.2017.1367096

Herranz M. \& Leander B. 2016. Redescription of Echinoderes ohtsukai Yamasaki and Kajihara, 2012 and E. kozloffi Higgins, 1977 from the Northwest Pacific coast, including the first report of a potential invasive species of kinorhynch. Zoologischer Anzeiger 265: 108-126.

https://doi.org/10.1016/j.jcz.2016.02.004

Herranz M., Yangel E. \& Leander B. 2018. Echinoderes hakaiensis sp. nov.: a new mud dragon (Kinorhyncha, Echinoderidae) from the northeastern Pacific Ocean with the redescription of Echinoderes pennaki Higgins, 1960. Marine Biodiversity 48: 303-325. https://doi.org/10.1007/s12526-017-0726-z

Higgins R.P. 1983. The Atlantic barrier reef ecosystem at Carrie Bow Cay, Belize, II: Kinorhyncha. Smithsonian Contributions to Marine Science 18: 1-131.

Karling T.G. 1954. Echinoderes levanderi n. sp. (Kinorhyncha) aus der Ostsee. Arkiv för Zoologi 7 : 189-192.

Kristensen R.M. \& Higgins R.P. 1991. Kinorhyncha. In: Harrison F.W. \& Ruppert E.E. (eds) Microscopic Anatomy of Invertebrates, Vol. 4, The Aschelminthes: 377-404. Wiley-Liss, New York.

Lang K. 1936. Undersökningar över Öresund, XXI: Einige Kleintiere aus dem Öresund. Kungliga Fysiografiska Sällskapets Handlingar Bd. 46 10: 1-8.

Levander K.M. 1900. Über das Herbst- und Winter-Plankton im Finnischen Meerbusen und in der Åland-See 1898. Acta Societatis pro Fauna et Flora Fennica 18: 1-25. 
Lundbye H., Rho H.S. \& Sørensen M.V. 2011. Echinoderes rex n. sp. (Kinorhyncha: Cyclorhagida) - the largest Echinoderes species found so far. Scientia Marina 75: 41-51.

https://doi.org/10.3989/scimar.2011.75n1041

Neuhaus B. 2013. Kinorhyncha (=Echinodera). In: Schmidt-Rhaesa A. (ed.) Handbook of Zoology. Gastrotricha, Cycloneuralia and Gnathifera. Volume 1: Nematomorpha, Priapulida, Kinorhyncha, Loricifera: 181-348. De Gruyter, Berlin/Boston.

Neves R.C., Sørensen M.V. \& Herranz M. 2016. First account on kinorhynchs from Portugal, with the description of two new species: Echinoderes lusitanicus sp. nov. and E. reicherti sp. nov. Marine Biology Research 12: 455-470. https://doi.org/10.1080/17451000.2016.1154973

Ostmann A., Nordhaus I. \& Sørensen M.V. 2012. First recording of kinorhynchs from Java, with the description of a new brackish water species from a mangrove-fringed lagoon. Marine Biodiversity 42: 79-91. https://doi.org/10.1007/s12526-011-0094-z

Pardos F., Herranz M. \& Sánchez N. 2016. Two sides of a coin: the phylum Kinorhyncha in Panama. II) Pacific Panama. Zoologischer Anzeiger 265: 26-47. https://doi.org/10.1016/j.jcz.2016.06.006

Sørensen M.V. 2014. First account of echinoderid kinorhynchs from Brazil, with the description of three new species. Marine Biodiversity 44: 251-274. https://doi.org/10.1007/s12526-013-0181-4

Sørensen M.V., Dal Zotto M., Rho H.S., Herranz M., Sánchez N., Pardos F. \& Yamasaki H. 2015. Phylogeny of Kinorhyncha based on morphology and two molecular loci. PLoS ONE 10 (7): e0133440. https://doi.org/10.1371/journal.pone.0133440

Sørensen M.V., Gąsiorowski L., Randsø P.V., Sánchez N. \& Neves R.C. 2016. First report of kinorhynchs from Singapore, with the description of three new species. Raffles Bulletin of Zoology 64: 3-27.

Sørensen M.V. \& Landers S.C. 2014. Two new species of Echinoderes (Kinorhyncha: Cyclorhagida) from the Gulf of Mexico. Frontiers in Marine Science 1 (8): 1-18. https://doi.org/10.3389/fmars.2014.00008

Reimer L. 1963. Zur Verbreitung der Kinorhyncha in der mittleren Ostsee. Zoologischer Anzeiger 171: 440-447.

Voipio A. (ed.) 1981. The Baltic Sea. Elsevier Scientific Publishing Company, Amsterdam/Oxford/New York.

Yamasaki H. 2016. Two new Echinoderes species (Echinoderidae, Cyclorhagida, Kinorhyncha) from Nha Trang, Vietnam. Zoological Studies 55: 32. https://doi.org/10.6620/ZS.2016.55-32

Yamasaki H. \& Fujimoto S. 2014. Two new species in the Echinoderes coulli group (Echinoderidae, Cyclorhagida, Kinorhyncha) from the Ryukyu Islands, Japan. ZooKeys 382: 27-52.

https://doi.org/10.3897/zookeys.382.6761

Yamasaki H. \& Kajihara H. 2012. A new brackish-water species of Echinoderes (Kinorhyncha: Cyclorhagida) from the Seto Inland Sea, Japan. Species Diversity 17: 109-118.

Zelinka C. 1928. Monographie der Echinodera. Verlag Wilhelm Engelmann, Leipzig.

Manuscript received: 9 October 2017

Manuscript accepted: 28 November 2017

Published on: 17 May 2018

Topic editor: Rudy Jocqué

Desk editor: Eva-Maria Levermann 
Printed versions of all papers are also deposited in the libraries of the institutes that are members of the EJT consortium: Muséum national d'Histoire naturelle, Paris, France; Botanic Garden Meise, Belgium; Royal Museum for Central Africa, Tervuren, Belgium; Natural History Museum, London, United Kingdom; Royal Belgian Institute of Natural Sciences, Brussels, Belgium; Natural History Museum of Denmark, Copenhagen, Denmark; Naturalis Biodiversity Center, Leiden, the Netherlands; Museo Nacional de Ciencias Naturales-CSIC, Madrid, Spain; Real Jardín Botánico de Madrid CSIC, Spain; Zoological Research Museum Alexander Koenig, Bonn, Germany. 